University of Nebraska - Lincoln

DigitalCommons@University of Nebraska - Lincoln

\title{
Effects of Dried Distillers Grains and Equivalent Undegradable Intake Protein or Ether Extract on Performance and Forage Intake of Heifers Grazing Smooth Bromegrass Pastures
}

\author{
J. C. Macdonald \\ Texas Agricultural Experiment Station, Amarillo \\ Terry J. Klopfenstein \\ University of Nebraska-Lincoln, tklopfenstein1@unl.edu \\ Galen E. Erickson \\ University of Nebraska-Lincoln, gerickson4@unl.edu \\ W. A. Griffin \\ University of Nebraska-Lincoln
}

Follow this and additional works at: https://digitalcommons.unl.edu/animalscifacpub

Part of the Animal Sciences Commons

Macdonald, J. C.; Klopfenstein, Terry J.; Erickson, Galen E.; and Griffin, W. A., "Effects of Dried Distillers Grains and Equivalent Undegradable Intake Protein or Ether Extract on Performance and Forage Intake of Heifers Grazing Smooth Bromegrass Pastures" (2007). Faculty Papers and Publications in Animal Science. 479.

https://digitalcommons.unl.edu/animalscifacpub/479

This Article is brought to you for free and open access by the Animal Science Department at DigitalCommons@University of Nebraska - Lincoln. It has been accepted for inclusion in Faculty Papers and Publications in Animal Science by an authorized administrator of DigitalCommons@University of Nebraska - Lincoln. 


\title{
Effects of dried distillers grains and equivalent undegradable intake protein or ether extract on performance and forage intake of heifers grazing smooth bromegrass pastures ${ }^{1}$
}

\author{
J. C. MacDonald, ${ }^{2}$ T. J. Klopfenstein, ${ }^{3}$ G. E. Erickson, and W. A. Griffin \\ Department of Animal Science, University of Nebraska, Lincoln 68583
}

\begin{abstract}
Crossbred heifers $(\mathrm{n}=120$; $\mathrm{BW}=368$ $\mathrm{kg}, \mathrm{SD}=39 \mathrm{~kg}$ ) were used to determine effects of dried distillers grains (DDG) and relative contributions of undegradable intake protein (UIP) and fat (ether extract, EE) in DDG on ADG and forage intake (FI). Heifers rotationally grazed six 3.5 -ha, smooth bromegrass paddocks $(\mathrm{IVDMD}=65.7 \%, \mathrm{CP}=20.8 \%, \mathrm{UIP}=2.17 \%$, DM basis). Heifers were blocked by previous ADG and allotted to treatments in a $3 \times 3+1$ factorial design. Factors were source and level of supplementation. Supplements were as follows: 1 ) DDG (UIP $=15.8 \%, \mathrm{EE}=$ 9.67\%), 2) corn gluten meal $(\mathrm{CGM}$; UIP $=31.6 \%, \mathrm{EE}=$ $0.83 \%$ ), or 3 ) corn oil (OIL; UIP $=0.74 \%, \mathrm{EE}=19.3 \%$ ). Amounts of DDG were $750,1,500$, or $2,250 \mathrm{~g} / \mathrm{d}$, whereas amounts of CGM and OIL were 375,750 , or $1,125 \mathrm{~g} /$ d. Supplements containing CGM and OIL were fed in amounts that provided UIP and EE, respectively, equivalent to those of the DDG. Contrasts of interest were DDG vs. CGM and DDG vs. OIL. Control heifers were fed $250 \mathrm{~g} / \mathrm{d}$ of a supplement containing corn bran and molasses (UIP $=0.92 \%, \mathrm{EE}=1.13 \%$ ). Heifers were supplemented individually. Treatments were separated by regressing the response variables on grams of nutrient
\end{abstract}

(DM, UIP, or EE) intake per kilogram of BW, because not all heifers consumed their allotment of supplement. Supplemental DDG resulted in a linear increase in ADG $(P<0.01)$, whereas CGM tended to increase ADG $(P=0.14)$ but at a rate that was $39 \%$ of that for DDG, representing a response to MP. Supplementation of OIL did not affect ADG $(P=0.25)$ and tended to result in ADG less than that of DDG $(P=0.09)$. Supplementation with DDG had no effect $(P=0.63)$ on FI when predicted by the use of chromic oxide but tended $(P=0.07)$ to decrease FI when it was predicted from ADG using NE equations. Despite the differences between methods in the significance of the effect of DDG, the rates of substitution agreed $(-0.50$ and -0.45 for chromic oxide and $\mathrm{NE}$ equations, respectively), suggesting that the chromic oxide method was less sensitive in assessing FI. Supplementation with CGM decreased FI $(P<0.01)$, but FI for CGM did not differ from that of DDG when the chromic oxide method was used $(P=0.19)$. Corn oil had no effect on FI $(P=0.42)$. Increased ADG and decreased FI observed from DDG supplementation is not independently explained by UIP or EE contained in DDG.

Key words: dried distillers grains, fat, forage intake, pasture, supplementation, undegradable intake protein

(C)2007 American Society of Animal Science. All rights reserved.

J. Anim. Sci. 2007. 85:2614-2624

doi:10.2527/jas.2006-560

\section{INTRODUCTION}

Feeding dried distillers grains (DDG) can increase ADG in growing cattle consuming both low-quality and high-quality forages (Loy et al., 2003; Morris et al.,

\footnotetext{
${ }^{1}$ A contribution of the University of Nebraska Agricultural Research Division, supported in part by funds provided through the Hatch Act. We wish to thank Kathy Hanford for assistance with statistical analyses.

${ }^{2}$ Present address: Texas Agricultural Experiment Station, 6500 Amarillo Blvd. W., Amarillo, TX 79106.

${ }^{3}$ Corresponding author: tklopfenstein1@unl.edu

Received August 18, 2006.

Accepted May 29, 2007.
}

2005), but the reason for increased gain is not fully elucidated. Cattle consuming actively growing forages will respond to undegradable intake protein (UIP supplementation, because the protein in the forage is highly degraded in the rumen, causing a MP deficiency (Klopfenstein, 1996; Creighton et al., 2003). Dried distillers grains contain 15 to $20 \%$ UIP (DM basis); thus, it is possible that UIP is responsible for the additional gain. However, DDG also contains 8 to $12 \%$ fat (DM basis). Thus, additional energy may also increase ADG. The relative contributions of these nutrients to the performance of cattle grazing forages remains undocumented, and their reported discoveries are important, because DDG nutrient compositions will change as the milling industry continues to alter the manner in which it processes corn. 
In addition to quantifying supplementation effects of DDG on ADG, it is also important to quantify effects on forage intake. Although ADG may be important to stocker operators, cow-calf producers may prefer to reduce forage intake vs. increasing body condition so that greater numbers of cows can be managed on a fixed land base. If specific nutrients in DDG affect $\mathrm{ADG}$ and forage intake differently, perhaps different products could be derived from the dry-milling process that would more precisely meet producer needs.

Our objective was to determine effects of DDG supplementation to cattle grazing actively growing forages on ADG and forage intake. Additionally, the relative contributions of UIP and fat contained in DDG were evaluated on effects on performance and forage intake of growing cattle grazing high-quality forage. Because MP may be limiting, and bacterial CP (BCP) is a primary source of MP for grazing cattle, the effects of supplementing DDG and its nutrients (UIP and fat) on BCP flow were evaluated.

\section{MATERIALS AND METHODS}

\section{Animal Management, Experimental Design, and Experimental Treatments}

All animals were managed in accordance to protocols approved by the Animal Care and Use Committee at the University of Nebraska.

One hundred twenty crossbred heifers (368 kg of $\mathrm{BW}, \mathrm{SD}=39 \mathrm{~kg}$ ) were used to determine the relative contributions of UIP and fat measured as ether extract (EE) in DDG on animal performance, forage intake, and relative differences in BCP flow. Heifers rotationally grazed 6 smooth bromegrass paddocks, which were 3.5 ha each. Heifers were rotated daily and were gathered each morning to provide supplements to each heifer individually using a Calan gate system. Paddocks were managed so that forage availability did not limit animal performance. The first $56 \mathrm{~d}$ of the trial were a time of rapid forage growth. During this time, heifers rotationally grazed 4 of the 6 paddocks so that forage was not limiting to animal performance, but forage regrowth was stimulated. The remaining 2 paddocks were retained early in the trial to be used if rainfall became limiting to forage growth. These 2 paddocks were flash-grazed with heavy grazing pressure for a short period to remove approximately $75 \%$ of the biomass at a midpoint during this time to ensure that the plants did not enter reproductive stages of growth. Heifers used for flash-grazing were not associated with the current trial. During the last $28 \mathrm{~d}$, when forage growth had slowed, heifers rotationally grazed all 6 pastures so that animal performance was not limited by forage availability.

Julian dates were used to describe the time effects of the trial. The trial was $84 \mathrm{~d}$ in length and occurred from Julian d 114 to 198 . Heifers were limit-fed a common diet at $1.75 \%$ of BW daily for $5 \mathrm{~d}$ at the begin-
Table 1. Composition (\% of DM) of supplements fed to heifers grazing smooth bromegrass ${ }^{1}$

\begin{tabular}{lcccc}
\hline \hline & \multicolumn{5}{c}{ Treatment $^{2}$} \\
\cline { 2 - 5 } Item & DDG & CGM & OIL & Control \\
\hline Ingredient & & & & \\
$\quad$ Dried distillers grains & 100.0 & - & - & - \\
Corn gluten meal & - & 57.4 & - & - \\
Corn oil & - & - & 18.4 & - \\
Corn bran & - & 34.6 & 73.6 & 92.0 \\
Molasses & - & 8.0 & 8.0 & 8.0 \\
Nutrient composition, \% of DM & & & & \\
CP & 31.0 & 45.9 & 11.3 & 13.9 \\
UIP & 15.8 & 31.6 & 0.74 & 2.07 \\
Ether extract & 9.67 & 0.83 & 19.3 & 1.23 \\
\hline
\end{tabular}

${ }^{1}$ All supplements provided $25 \mathrm{~g} / \mathrm{d}$ of sodium chloride and $15 \mathrm{~g} / \mathrm{d}$ of chromic oxide for use as a fecal output marker.

${ }^{2} \mathrm{DDG}=$ dried distillers grains; $\mathrm{CGM}=$ corn gluten meal; $\mathrm{OIL}=$ corn oil.

${ }^{3}$ Undegradable intake protein.

ning and end of the trial. The common diet consisted of $33 \%$ corn cobs, $33 \%$ sorghum silage, $33 \%$ wet corn gluten feed, and $1 \%$ of a supplement (DM basis) that provided minerals and vitamins. Body weights were measured for 3 consecutive days at the beginning and end of the trial to minimize variation in gut fill. Heifers were also weighed for 3 consecutive days every $28 \mathrm{~d}$ during the trial for interim BW, but heifers were not limit-fed for these BW. Heifers were blocked by ADG from a previous experiment and assigned randomly to receive 1 of 10 treatments in a $3 \times 3+1$ factorial arrangement, with 3 supplements, 3 levels of supplement feeding, and a control. Each heifer was an experimental unit, and there were 12 heifers per treatment.

Supplements (Table 1) included DDG (15.8\% UIP, 9.67\% EE), corn gluten meal (CGM; 31.6\% UIP, $0.83 \%$ $\mathrm{EE}$ ), or corn oil (OIL; 0.74\% UIP, $19.3 \% \mathrm{EE}$ ). Corn gluten meal and corn oil were selected as sources of UIP and fat, respectively, because, like DDG, they are derived from corn, and therefore, their AA and fatty acid profiles, respectively, were assumed to be similar to those of DDG.

Amounts of DDG supplementation were 750, 1,500, and $2,250 \mathrm{~g} / \mathrm{d}$, whereas CGM and OIL were supplemented at 375,750 , and $1,125 \mathrm{~g} / \mathrm{d}$ of DM. Although heifers supplemented with CGM and OIL were offered half the DM compared with heifers supplemented with DDG, their respective concentrations of UIP and fat were doubled, such that the levels of these nutrients matched those found in respective levels of DDG supplementation. This was done to minimize the amount of supplement offered to heifers consuming CGM and OIL, so they would consume their entire supplement offering. Corn bran was used as a carrier, and molasses was included to bind the supplement and improve palatability for heifers consuming CGM and OIL. Salt was included in all supplements at levels that provided $25 \mathrm{~g} / \mathrm{d}$, and chromic oxide (Landers-Segal Color Co., 
Montvale, NJ) was included at levels that provided 15 $\mathrm{g} / \mathrm{d}$. Chromic oxide was used as a marker for fecal output and was included in the supplements for $3 \mathrm{~d}$ before and through the end of fecal collections (Julian d 128 to 132,156 to 160 , and 184 to 188). Chromic oxide was removed from all supplements at other times. Control heifers were offered $200 \mathrm{~g} / \mathrm{d}$ of a supplement containing corn bran and molasses (UIP $=0.92 \%$, $\mathrm{EE}=1.13 \%)$ to serve as a carrier for salt and chromic oxide. Supplement refusal for each heifer was collected and weighed weekly. Fecal and spot (periodic) urine samples were collected for 3 consecutive days during each 28 -d period. The median Julian day for each collection was 132,160 , and 188. Samples were immediately frozen at $-4^{\circ} \mathrm{C}$ until further analysis.

\section{Diet Sample Collection and Analysis and Analysis of Supplement Ingredients}

Diet samples were collected from 2 paddocks during each grazing rotation using 2 ruminally fistulated heifers that had been ruminally evacuated ( 2 heifers per paddock) and allowed to graze for 30 to $45 \mathrm{~min}$. One paddock had been grazed the previous day, and the second was grazed immediately after collection. It was assumed that by collecting samples before and after grazing, the samples represented the average forage quality available to heifers at that time. Diet samples were frozen immediately after collection at $-4^{\circ} \mathrm{C}$ until further analysis.

Diet samples were lyophilized $\left(-50^{\circ} \mathrm{C}\right)$ and ground with a Wiley mill (Thomas Scientific, Swedesboro, NJ) through a 2-mm screen for in situ analysis and through a 1-mm screen for all other laboratory analyses. The IVDMD was determined for diet samples and corn bran carrier used in supplements using the Tilley and Terry method (1963), which was modified by the addition of $1 \mathrm{~g} / \mathrm{L}$ of urea to the McDougall's buffer (Weiss, 1994). Total tract DM digestibility (TTDMD) was determined by including in the in vitro run 5 hay samples of varying qualities that had known total tract (in vivo) DM digestibilities. The IVDMD values for these standards were regressed on their known digestibilities, and the resulting equation $(\mathrm{y}=0.792 \mathrm{x}+6.3$, where $\mathrm{x}=$ IVDMD and $\mathrm{y}=$ TTDMD) was used to calculate TTDMD. This method for determining TTDMD was recently described by Geisert et al. (2006) and has previously been described and validated by Weiss (1994). Crude protein was determined in diet samples, corn bran carrier, CGM, and DDG by the combustion method (AOAC, 1996) using a combustion $\mathrm{N}$ analyzer (Leco FP-528, St. Joseph, MI). The IVDMD values were used to determine 0.75 mean retention time for UIP determination of diet samples and corn bran carrier by ruminal incubation, according to the procedures of Haugen et al. (2006b). The rumen incubation time was: $[(1 /$ rate of passage $)+10 \mathrm{~h}] \times 0.75$, where rate of passage $(\% / \mathrm{h})=[0.07 \times(\mathrm{IVDMD}, \%)]-0.20$. Digestibility of UIP and total tract indigestible protein
(TTIDP) were also determined for diet samples and corn bran carrier according to procedures of Haugen et al. (2006a).

For in situ analysis of DDG and CGM, the procedure was modified in that samples were ruminally incubated for $16 \mathrm{~h}$ and were not extracted with neutral detergent solution to remove attached bacteria. Two ruminally and duodenally fistulated steers given ad libitum access to smooth bromegrass hay were utilized for all in situ procedures and IVDMD analyses. For in situ analysis of diet samples and corn bran, quadruplicate bags were incubated per steer; 2 bags were used for UIP determination and 2 bags for TTIDP determination. For in situ analysis of DDG and CGM, 10 bags were incubated per steer to ensure adequate residue was available for analysis. Four bags were used for duplicate composites for UIP determination ( 2 random bags combined per composite), and 6 bags were used for duplicate composites for TTIDP determination (3 random bags combined per composite). Neutral detergent fiber (Van Soest et al., 1991) was determined for corn bran carrier, CGM, and DDG.

\section{Estimation of Forage Intake and BCP Flow}

Forage intake was estimated using 2 methods. The first was by analysis of $\mathrm{Cr}$ in feces and supplements. Fecal samples were lyophilized $\left(-50^{\circ} \mathrm{C}\right)$, composited by collection period, and ground through a 1-mm screen using a cyclotech sample mill (Foss North America, Eden Prairie, MN). Fecal samples were ashed, digested with a phosphoric acid-manganese sulfate solution (Williams et al., 1962), and analyzed for Cr using a Varian Spectra AA-30 atomic absorption spectrophotometer (Varian, Walnut Creek, CA). Fecal output was determined by dividing $\mathrm{Cr}$ intake (Cr offered in supplement minus $\mathrm{Cr}$ in orts) by $\mathrm{Cr}$ concentration in feces. The amount of feces due to supplement indigestibility was subtracted from total fecal output to yield feces from forage. Supplement indigestibilities were determined from mobile bag DM residue associated with TTIDP estimates. Supplement indigestibilities were $27.5,17.9,25.4$, and $12.3 \%$ for control, DDG, OIL, and CGM, respectively. Fecal output from forage was divided by forage indigestibility ( 1 - TTDMD) to yield forage intake.

The second method for determining forage intake was an energetic model based on the NE equations in the beef NRC model (1996). The guiding principle employed was to back-calculate forage intake from individual animal ADG, DDG intake, and known digestible energy densities for forage and DDG. This method was only used to determine forage intake for heifers consuming DDG and was developed from a data set reported by Morris et al. (2005), who supplemented graded levels of DDG (TDN $=90 \%)$ and provided ad libitum access to a high-quality forage (TDN = $62.25 \%$ ). Therefore, the model development data set provided measurements of ADG, forage intake, and 
supplement intake for each animal. Net energy for maintenance and gain were calculated from estimates of TDN (assumed to be TTDMD) using the NE equations in the beef NRC (1996). Known intakes of forage and DDG were used to predict animal ADG. It is well documented that NE adjusters are needed to accurately predict animal performance in high-forage diets (Patterson et al., 2000; Block et al., 2006). Therefore, $\mathrm{NE}$ adjusters were calculated for each animal in the model development data set so that their TDN intake (calculated from the proportions of forage and DDG consumed) accurately predicted their ADG. Net energy adjusters were regressed on dietary TDN, which resulted in the following equation: $\mathrm{y}=2.592 .116 \mathrm{x}$, where $\mathrm{x}=$ the percentage of TDN of the diet and $\mathrm{y}=$ the NE adjuster (as \%). This equation can be used to predict appropriate NE adjusters in cattle consuming highquality forage and DDG if TDN intake is known. However, if a component of TDN intake, such as TDN from forage intake, is not known, an iterative process may be used to predict TDN intake, thereby yielding forage intake if DDG intake is known.

To calculate forage intake for each heifer in the current data set, maintenance energy requirements were initially taken from DDG intake, because it was a known variable. The remaining $\mathrm{NE}_{\mathrm{g}}$ from $\mathrm{DDG}$ was applied to retained energy, and the amount of additional (or reduced) $\mathrm{NE}_{\mathrm{g}}$ needed to achieve the observed ADG was used to calculate forage intake as an initial estimate. This was the end of the first iteration. During the second iteration, the proportions of DDG and forage were used to calculate a diet, and a $\mathrm{NE}$ adjuster was applied based on the TDN of the diet as predicted from the equation described above. Maintenance energy requirements were taken from the diet (rather than from DDG only). Average daily gain was predicted from this diet using the NE adjuster that had been applied and compared with the actual ADG observed for each animal. Forage intake was adjusted until predicted ADG matched observed ADG. This was the end of the second iteration. In subsequent iterations, diets were calculated from the proportions of DDG and forage as predicted from the previous iteration, NE adjusters were applied to the diet, ADG was predicted, and forage intake was altered until predicted ADG matched observed ADG. Iterations continued until there was no change in the calculated TDN concentration of the diet when calculated ADG matched observed ADG. This is a similar approach to that employed by Owens et al. (2002) for use in feedlot cattle.

Relative differences in BCP flow were determined by analysis of the ratio of purine derivatives to creatinine (PD:C) in spot (periodic) urine samples (Shingfield and Offer, 1998). Urine samples were composited by collection period, diluted with 1 part urine and 39 parts urine diluents (Shingfield and Offer, 1998), and analyzed for purine derivatives and creatinine by HPLC analysis (Waters Corp., Milford, MA) according to the procedure of Shingfield and Offer (1999).

\section{Statistical Analysis}

Statistical analysis was conducted using the MIXED procedure (SAS Inst. Inc, Cary, NC), with block considered to be a random effect. Many heifers consumed less supplement than was offered, such that it was not logical to analyze the data using orthogonal polynomials based on treatment allotments. To determine if actual supplement intake should be used as a covariate for regression analysis, supplement intakes were analyzed as a $3 \times 3$ factorial, with control heifers removed. Supplement source, supplement level, 28-d collection period, and all 2- and 3-way interactions were included in the model. Intakes were expressed as a percentage of the DM offered, because planned DMI were different. Results (data not shown) suggested that supplement intakes were different than those that were planned. Therefore, actual average daily UIP and EE intakes, reported as grams of nutrient intake per kilogram of BW, were used as covariates for regression analysis comparing DDG vs. CGM and DDG vs. OIL, respectively. Additionally, the response to DDG supplementation of $\mathrm{ADG}$, forage intake from chromic oxide analysis and from the energetic model, and relative changes in the flow of $\mathrm{BCP}$ to the small intestine were evaluated alone (not compared with CGM or OIL) so that it could be expressed as grams of DDG DMI per kilogram of BW. This was done so that these data could be easily related to DM supplementation rates used in production and so that the forage intake predicted from the energetic model could be easily compared with forage intake predicted from chromic oxide analysis. We recognize that analyzing a subset of the data reduces the degrees of freedom for error, increasing the risk of committing a type II error. Therefore, it is recommended that more emphasis be placed on statistical differences reported in comparisons of DDG to CGM and OIL. Regression equations were developed using the solutions option in SAS, with the greatestorder polynomial that was significant $(P<0.05)$ included in the equation. The statistical model and estimate statements were developed so that it could be determined if each slope was different from 0 and if the slopes were different from each other. Intercept differences were tested, and if found to be nonsignificant $(P>0.05)$, intercepts were forced through the response of control. Repeated measures were used to test the effects of time. Forage intake from chromic oxide analysis, PD:C, and ADG utilized an unstructured covariance pattern, whereas characteristics associated with forage diet samples utilized a compound symmetry covariance structure. Covariance patterns were selected by their reduction of Akaike's criterion relative to the unstructured pattern (Littell et al., 2002). Models developed to evaluate forage diet sample characteristics included paddock (before and after 
Table 2. Characteristics of selected supplement ingredients

\begin{tabular}{|c|c|c|c|c|c|}
\hline Ingredient & $\begin{array}{c}\mathrm{NDF}, \\
\% \text { of } \\
\mathrm{DM}\end{array}$ & $\begin{array}{l}\mathrm{CP} \\
\% \text { of } \\
\mathrm{DM}\end{array}$ & $\begin{array}{c}\text { UIP, } \\
\% \text { of } \\
\mathrm{CP}\end{array}$ & $\begin{array}{c}\text { TTIDP, }{ }^{2} \\
\% \text { of } \\
\text { CP }\end{array}$ & $\begin{array}{c}\text { UIPDIG, }{ }^{3} \\
\% \text { of } \\
\text { UIP }\end{array}$ \\
\hline Dried distillers grains & 41.7 & 31.0 & 51.3 & 5.70 & 88.8 \\
\hline Corn gluten meal & 16.0 & 70.1 & 77.8 & 3.97 & 94.9 \\
\hline Corn bran & 76.5 & 14.4 & 18.6 & 12.7 & 31.3 \\
\hline Molasses $^{4}$ & - & 8.5 & 0.0 & - & - \\
\hline $\mathrm{SEM}^{5}$ & - & - & 2.0 & 1.8 & 3.4 \\
\hline
\end{tabular}

${ }^{1}$ Undegradable intake protein.

${ }^{2}$ Total tract indigestible protein, \% of CP.

${ }^{3}$ Undegradable intake protein digestibility.

${ }^{4}$ Values from the NRC (1996).

${ }^{5} \mathrm{n}=4$.

grazing), but effects of paddock were ignored, because the intent was to use the average of the 2 paddocks to evaluate forage quality characteristics. Effects of time on ADG were tested. However, if time $\times$ ADG interactions were nonsignificant $(P>0.10)$, beginning and end $\mathrm{BW}$ were used to describe the main effects of $\mathrm{ADG}$, because these were limit-fed BW that minimized variation in gut fill.

\section{RESULTS AND DISCUSSION}

The supplement intake analysis (data not shown) resulted in a tendency for an interaction of supplement source and supplement level $(P=0.13)$. Use of the slice option in SAS elucidated that supplement intakes tended to differ at the lowest level $(P=0.11)$ and greatest level $(P=0.07)$ of supplementation. The tendency for intakes of supplements to differ across levels of supplementation suggested to us that use of actual supplement intake as a covariate in regression analysis was more appropriate than the preplanned contrasts. Individual DDG intakes averaged across the study and expressed in grams of DM per kilogram of BW provide the range of supplementation about which conclusions can be drawn. To determine this, contrasts were developed to compare intakes of supplement sources at the greatest level of supplementation (data not shown). Relative intakes of DDG and OIL did not differ $(P=0.58)$, whereas intakes of CGM were significantly greater than OIL $(P=0.02)$ and tended to be greater than DDG $(P=0.09)$. Because application of these data was intended for DDG, and because OIL was not different from the greatest level of DDG consumption and CGM tended to be greater than the greatest level of DDG consumption, it seemed reasonable to relate the levels of supplementation to the observed DDG intakes in the study, which was from 0 to approximately $7.5 \mathrm{~g} \mathrm{DM} / \mathrm{kg}$ of BW.

No period $\times$ treatment interactions were detected $(P$ $>0.20$ ), so main effects are reported. Also, differences in intercepts were determined to be nonsignificant for all comparisons $(P>0.05)$, so intercepts were forced through the response of the control.
Protein and NDF characteristics of supplement ingredients are shown in Table 2 . Corn oil was not analyzed, because it was assumed to contribute no protein or NDF. Neutral detergent fiber content varied greatly among supplements, because corn bran was used as the carrier. Supplements contained 41.7, 35.7, and $56.3 \%$ NDF (DM basis) for DDG, CGM, and OIL, respectively. Accounting for differences in DM offered, the UIP and OIL supplements provided 43 and $68 \%$ as much NDF as DDG, respectively, which may have affected BCP production. Crude protein and UIP values were used to formulate the CGM supplement, but UIP digestibility values were obtained retrospectively. The NRC (1996) model assumes that all UIP is $80 \%$ digestible. These data clearly show substantial variation in UIP digestibility ranging from 31.3 to $94.9 \%$ of UIP (Table 2). Although corn gluten meal had the greatest UIP digestibility, when accounting for the corn bran and differences in supplemental DM offered, CGM supplement provided $94 \%$ as much MP as DDG; therefore, the 2 supplements remain comparable in the amount of UIP and MP provided to heifers.

There was a tendency for forage TTDMD (Table 3) to change quadratically $(P=0.09)$ over time. Therefore, a quadratic equation was used to describe TTDMD and to calculate forage indigestibility for each of the 3 periods for use in forage intake calculations using chromic oxide. Forage indigestibility was 41.0, 42.3, and $42.6 \%$ for Julian dates 132,160 , and 188 , respectively. An average TTDMD of $58.2 \%$ was used as the TDN value for the forage in the energetic model to predict forage intake.

There was also a tendency for quadratic changes over time in $\mathrm{CP}(P=0.07)$ and UIP $(P=0.11)$, a significant quadratic increase over time in TTIDP $(P=0.02)$, and no change over time in UIP digestibility $(P>0.27)$. Digestibility of UIP averaged $44.5 \%$, which is less than $80 \%$ assumed by NRC (1996). Haugen et al. (2006a) reported values of 38.6 and $27.1 \%$ UIP digestibility of clipped smooth bromegrass samples collected in June and July, respectively. Diet samples in the current data set ranged from 41.7 to $45.2 \%$ during a similar time frame. Haugen et al. (2006a) also reported UIP 
Table 3. Characteristics of diet samples collected from each grazing rotation

\begin{tabular}{|c|c|c|c|c|c|c|}
\hline Item & IVDMD & TTDMD $^{1}$ & $\mathrm{CP}$ & $\begin{array}{c}\mathrm{UIP}^{2} \\
\% \text { of } \mathrm{CP}\end{array}$ & $\begin{array}{l}\text { TTIDP, } \\
\% \text { of } \mathrm{CP}\end{array}$ & $\begin{array}{l}\text { UIPDIG, } \\
\% \text { of UIP }\end{array}$ \\
\hline \multicolumn{7}{|c|}{ Day of sampling ${ }^{5}$} \\
\hline 125 & 68.2 & 60.3 & 21.9 & 8.8 & 2.26 & 40.7 \\
\hline 133 & 68.3 & 60.5 & 21.8 & 9.8 & 4.67 & 50.1 \\
\hline 141 & 63.1 & 56.3 & 19.7 & 10.9 & 5.93 & 44.8 \\
\hline 149 & 66.2 & 58.7 & 20.4 & 10.0 & 5.12 & 47.3 \\
\hline 157 & 63.3 & 56.4 & 20.1 & 10.5 & 5.94 & 42.3 \\
\hline 165 & 64.4 & 57.3 & 19.5 & 12.7 & 7.28 & 44.0 \\
\hline 177 & 68.2 & 60.3 & 22.5 & 9.7 & 5.90 & 41.7 \\
\hline 191 & 62.8 & 56.0 & 21.4 & 12.3 & 6.76 & 45.2 \\
\hline SEM $^{6}$ & 3.6 & 2.8 & 2.7 & 1.8 & 1.7 & 6.3 \\
\hline \multicolumn{7}{|l|}{$P$-value ${ }^{7}$} \\
\hline Linear & 0.55 & 0.54 & 0.68 & 0.08 & $<0.01$ & 0.57 \\
\hline Quadratic & 0.09 & 0.09 & 0.07 & 0.11 & 0.02 & 0.28 \\
\hline Cubic & 0.53 & 0.52 & 0.42 & 0.42 & 0.41 & 0.27 \\
\hline
\end{tabular}

${ }^{1}$ Total tract DM digestibility determined by including in the in vitro run 5 hay samples of varying qualities that had known total tract DM digestibilities (TTDMD). The IVDMD values for these standards were regressed on their known digestibilities, and the resulting equation $(\mathrm{y}=0.792 \mathrm{x}+6.3$, where $\mathrm{x}=$ IVDMD and $\mathrm{y}=$ TTDMD) was used to calculate TTDMD.

${ }^{2}$ Undegradable intake protein.

${ }^{3}$ Total tract indigestible protein.

${ }_{5}^{4}$ Undegradable intake protein digestibility.

${ }^{5}$ Julian date.

${ }^{6} \mathrm{n}=4$.

${ }^{7}$ Probabilities of linear, quadratic, and cubic trends determined with orthogonal polynomial contrasts.

values ranging from 11.4 to $17.3 \% \mathrm{CP}$ and TTIDP values of 6.9 to $12.5 \% \mathrm{CP}$. Values from the current trial ranged from 9.7 to $12.3 \% \mathrm{CP}$ for UIP and from 5.9 to 7.3\% CP for TTIDP during the same time frame. This suggests a greater proportion of forage protein was absorbed by the animals in the current trial. Differences could be attributed to environmental factors or inherent differences associated with clipping vs. using animals to collect diet samples. However, the conclusion from these data is that UIP digestibility of forage is substantially less than $80 \%$, which is consistent with the findings of Haugen et al. (2006a).

Average daily gain and PD:C decreased quadratically $(P<0.01$; Table 4$)$ in a manner consistent with decreasing forage quality, even though diet collection samples did not demonstrate a similar reduction $(\mathrm{Ta}-$ ble 3). However, both IVDMD and TTDMD indicate a general decline in forage quality with advancing season except for samples collected at Julian d 177. This sampling date may be artificially inflating estimates of forage quality at the end of the study period. Forage intake also increased quadratically $(P<0.01$; Table $4)$. There was a relatively large increase in forage intake at Julian d 188. Decreasing fiber digestibility is generally associated with decreased forage intake (Oba and Allen, 1999). If the estimate of TTDMD was artificially inflated due to samples collected on Julian d 177, forage intake estimates would be concurrently inflated when using the chromic oxide marker approach. Responses to DDG supplementation expressed as grams of DM per kilogram of BW are shown in Figure 1. Supplementation of DDG significantly increased ADG $(P<0.01)$. The slope of 0.065 is similar to the findings of Morris et al. (2005), who supplemented high-quality forages with DDG and reported a slope of 0.058. Comparisons of DDG to CGM and OIL are shown in Figures 2 and 3, respectively. Performance tended to be improved $(P=0.14)$ by CGM supplementation, whereas the slope for OIL was not different from $0(P=0.25)$. The response to DDG tended to be greater than the response to either CGM $(P=0.11)$ or OIL $(P=0.09)$. The slope for CGM was $39 \%$ the slope for

Table 4. Main effects of time on response variables

\begin{tabular}{|c|c|c|c|c|c|c|}
\hline \multirow[b]{2}{*}{ Item } & \multicolumn{3}{|c|}{ Julian date } & \multirow[b]{2}{*}{ SEM } & \multicolumn{2}{|c|}{$P$-value ${ }^{1}$} \\
\hline & 132 & 160 & 188 & & Linear & Quadratic \\
\hline $\mathrm{ADG}, \mathrm{kg}$ & 1.05 & 0.60 & 0.43 & 0.07 & $<0.01$ & $<0.01$ \\
\hline Forage intake ${ }^{2}$ & 17.2 & 17.1 & 21.3 & 1.06 & $<0.01$ & $<0.01$ \\
\hline $\mathrm{PD}: \mathrm{C}^{3}$ & 1.79 & 1.59 & 1.58 & 0.04 & $<0.01$ & $<0.01$ \\
\hline
\end{tabular}

${ }^{1}$ Probabilities of linear and quadratic trends determined with orthogonal polynomial contrasts.

${ }^{2}$ Estimated via chromic oxide analysis ( $/ \mathrm{kg}$ of $\mathrm{BW}$ ).

${ }^{3} \mathrm{PD}: \mathrm{C}=$ ratio of purine derivatives to creatinine. 

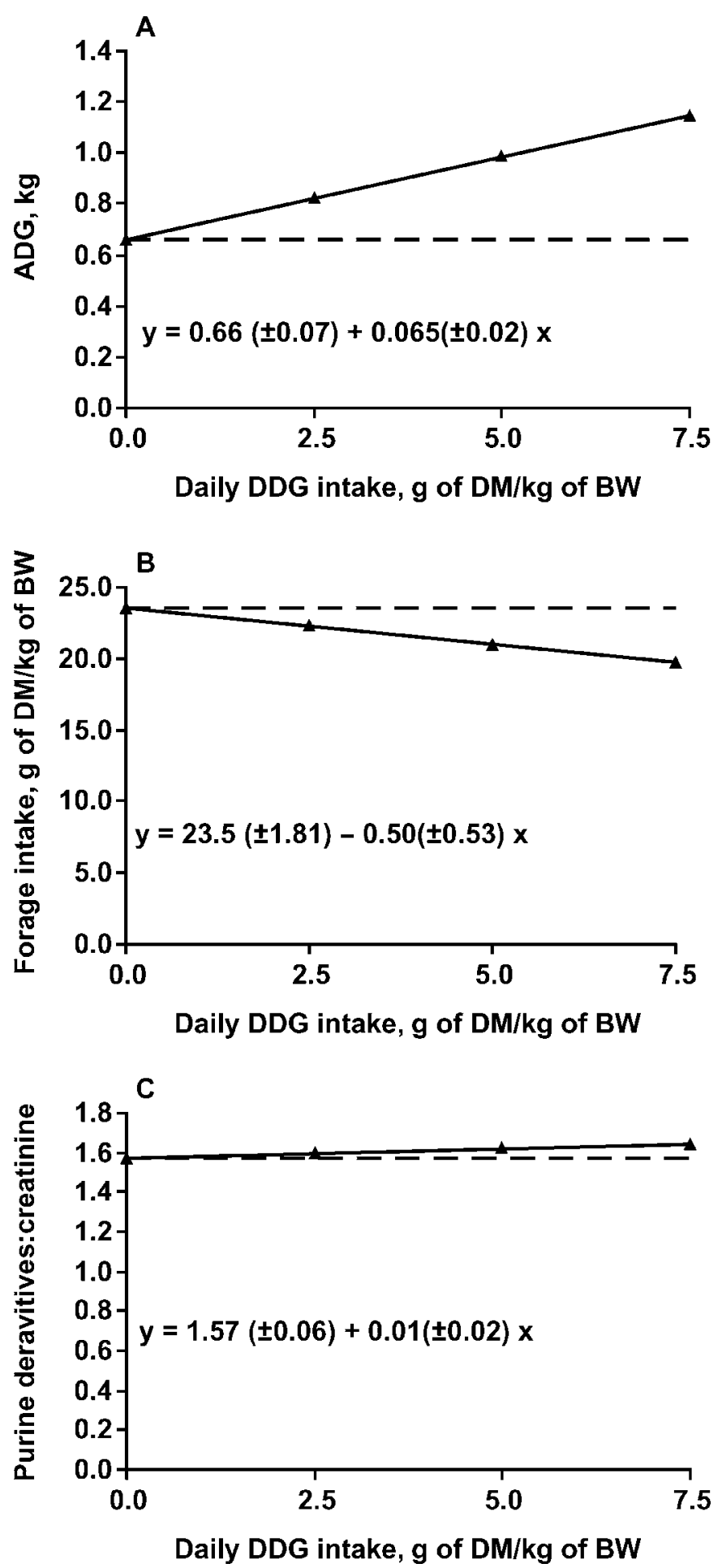

Figure 1. Effects of dried distillers grains (DDG) supplementation on (A) ADG, (B) forage intake estimated from chromic oxide analysis, and $(\mathrm{C})$ the ratio of purine derivatives to creatinine as an indication of bacterial CP flow. The dashed lines are reference values for the response of nonsupplemented control heifers. (A) DDG slope different from $0(P<0.01)$; (B) DDG slope different from $0(P=$ $0.63)$; and $(C)$ DDG slope different from $0(P=0.29)$.
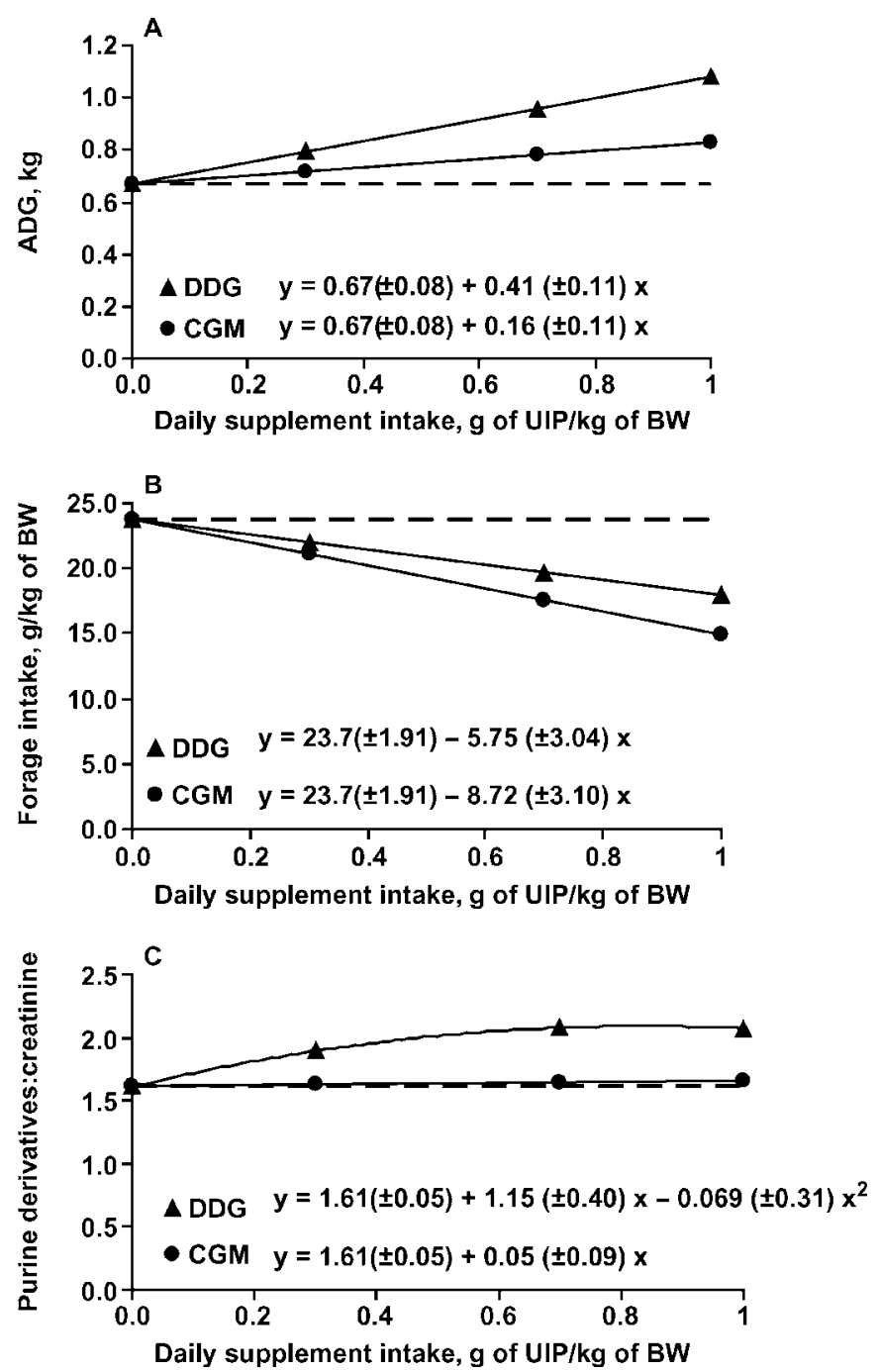

Figure 2. Effects of undegradable intake protein (UIP) supplementation from dried distillers grains (DDG) or corn gluten meal (CGM) on (A) ADG, (B) forage intake estimated from chromic oxide analysis, and (C) the ratio of purine derivatives to creatinine as an indication of bacterial $\mathrm{CP}$ flow. The dashed lines are reference values for the response of nonsupplemented control heifers. (A) DDG slope different from $0(P<0.01)$, CGM slope different from $0(P=0.14)$, and DDG slope different from CGM slope $(P=0.11)$; (B) DDG slope different from $0(P=0.27)$, CGM slope different from $0(P<0.01)$, and DDG slope different from CGM slope $(P=0.19)$; and $(C)$ DDG slope different from $0(P=0.03)$, CGM slope different from 0 $(P=0.56)$, and DDG slope different from CGM $(P<0.01)$.

DDG, which may represent the proportion of the response of DDG that is due to meeting a MP deficiency. The fact that the response of CGM is linear rather than quadratic may indicate cattle can use protein available in excess of the MP requirement for energy through deamination of the protein and metabolism of carbon skeletons. However, interpretations of these data are confounded by varying levels of the corn bran carrier in the supplements. Corn bran is a highly di- 

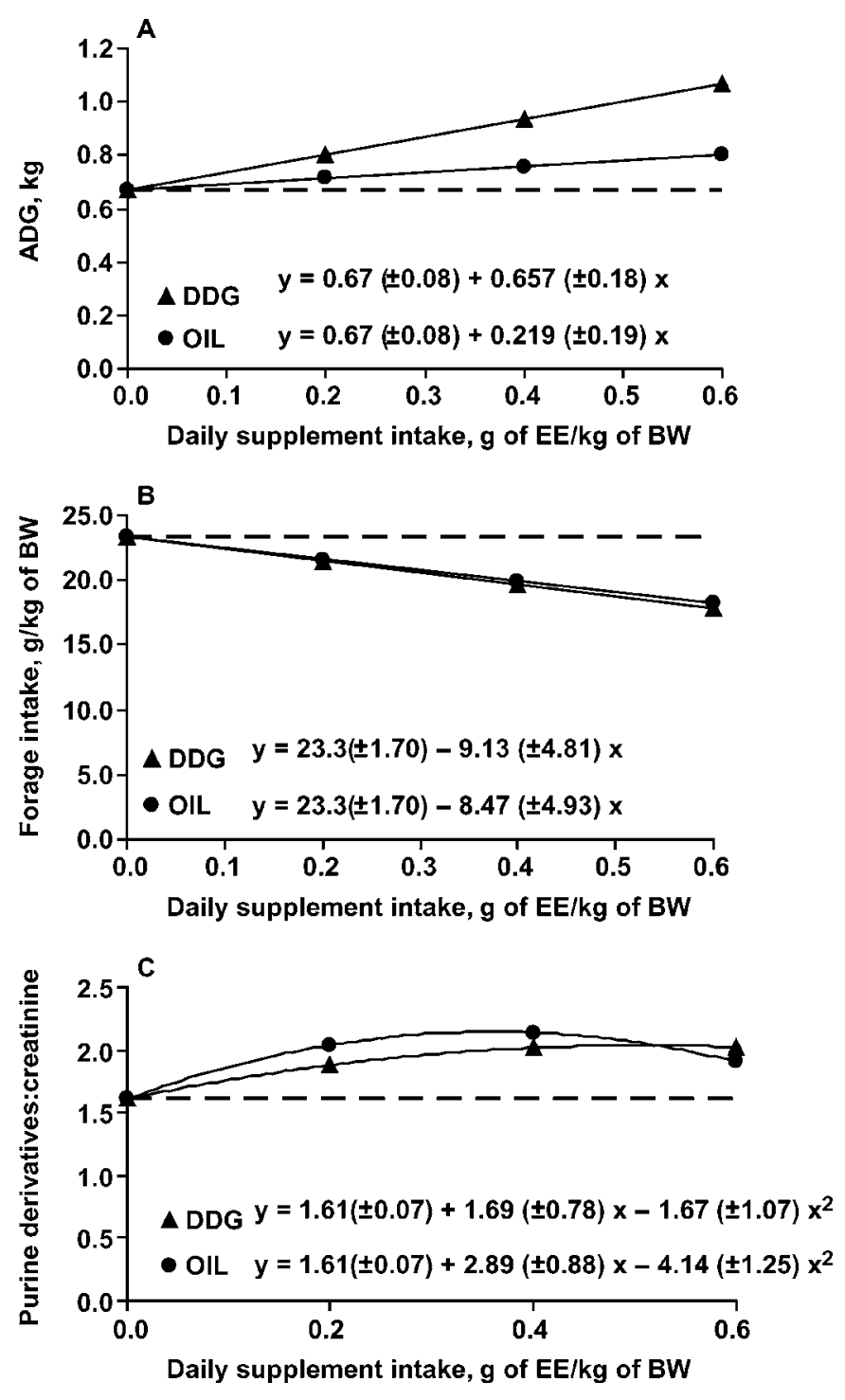

Figure 3. Effects of ether extract (EE) supplementation from dried distillers grains (DDG) or corn oil (OIL) on (A) ADG, (B) forage intake estimated from chromic oxide analysis, and $(C)$ the ratio of purine derivatives to creatinine as an indication of bacterial CP flow. The dashed lines are reference values for the response of nonsupplemented control heifers. (A) DDG slope different from 0 $(P<0.01)$, OIL slope different from $0(P=0.25)$, and DDG slope different from OIL slope $(P=0.09)$; (B) DDG slope different from $0(P=0.17)$, OIL slope different from $0(P$ $<0.42)$, and DDG slope different from OIL slope $(P=$ $0.73)$; and (C) DDG slope different from $0(P=0.05)$, OIL slope different from $0(P<0.01)$, and DDG slope different from OIL $(P<0.37)$.

gestible fiber source (Firkins et al., 1985) that may contribute to BCP production independently of the nutrients intended to be tested.

The use of CGM and OIL as sources of UIP and $\mathrm{EE}$, respectively, found in DDG carries the implicit assumption that AA and fatty acid profiles are similar. Goedeken et al. (1990) reported an AA profile of corn gluten meal expressed as a percentage of $\mathrm{CP}$ of $4.3 \%$ Arg, $1.9 \%$ His, $4.2 \%$ Ile, $16.5 \%$ Leu, $1.8 \%$ Lys, $2.7 \%$ Met, $6.6 \%$ Phe, $3.7 \% \mathrm{Thr}$, and $4.5 \%$ Val after $12 \mathrm{~h}$ of ruminal incubation. MacDonald (2006) reported an AA profile of DDG expressed as a percentage of CP of 7.5\% Arg, $4.2 \%$ His, $2.6 \%$ Ile, $10.4 \%$ Leu, $2.6 \%$ Lys, $1.4 \%$ Met, 3.2\% Phe, 3.3\% Thr, and 3.7\% Val after $16 \mathrm{~h}$ of ruminal incubation. Both authors agreed that ruminal incubation had little effect on the proportion of AA, which may suggest AA experience similar ruminal degradation. Although the proportion of some AA, such as Arg and His, appear to differ between the 2 sources, the profiles appear to be similar in that, like corn, they are low in Lys and His and high in Leu and Phe. Additionally, Paven et al. (2007) reported fatty acid profiles of $<0.1 \% 14: 0,10.8 \% 16: 0,1.96 \% 18: 0,28.5 \%$ $18: 1,55.7 \% 18: 2,1.3 \% 18: 3,0.75 \%$ other fatty acids, and $0.95 \%$ unidentified fatty acids for corn oil. Similarly, Leonardi et al. (2005) reported fatty acid profiles of $0.1 \% 14: 0,14.6 \% 16: 0,0.3 \% 16: 1,2.6 \% 18: 0,25.7 \%$ $18: 1,53.3 \% 18: 2,1.6 \% 18: 3,0.6 \% 20: 0$, and $0.75 \%$ other fatty acids for DDG. The values for Paven et al. (2007) and Leonardi et al. (2005) suggest the fatty acid profiles for corn oil and DDG are similar. Therefore, based on analyses reported in these papers, we concluded that CGM was a UIP source comparable to DDG, and corn oil was a fatty acid comparable source to DDG.

Paven et al. (2007) reported a tendency $(P=0.09)$ for a linear increase in the ADG of steers grazing endophyte-free tall fescue due to supplementation of corn oil at rates of $0,0.75$, or $1.5 \mathrm{~g} / \mathrm{kg}$ of $\mathrm{BW}$. This data set, collected in winter months with a differing forage type, demonstrates that corn oil may be an effective energy supplement in situations in which energy is limiting. The lack of response from adding energy from OIL supplementation in the current study may suggest MP is first limiting in these heifers, which is consistent with previous findings in similar production systems (Klopfenstein, 1996; Creighton et al., 2003). Supplying energy in the form of fat may not increase BCP flow, because ruminal microbes yield essentially no BCP from fat (NRC, 1996). Therefore, supplying additional energy without protein may not improve gain. However, the added response of DDG over CGM suggests that adding energy and protein in combination could provide a complementary effect and allow for additional gain. Other nutrients provided in DDG may also contribute to the additional gain, but we are unable to separate their relative contributions with these data.

Forage replacement rate can be defined as the unit reduction in forage intake per unit of supplement consumed. Morris et al. (2005) reported a forage replacement rate by DDG of -0.53 . The replacement rate from chromic oxide analysis of the current study was -0.50 (Figure 1), but the slope was not different from $0(P=$ $0.63)$. However, when the energetic model was employed, the slope was -0.45 (Figure 4 ), which tended to be different from $0(P=0.07)$. It is encouraging that the slopes from chromic oxide analysis and the 


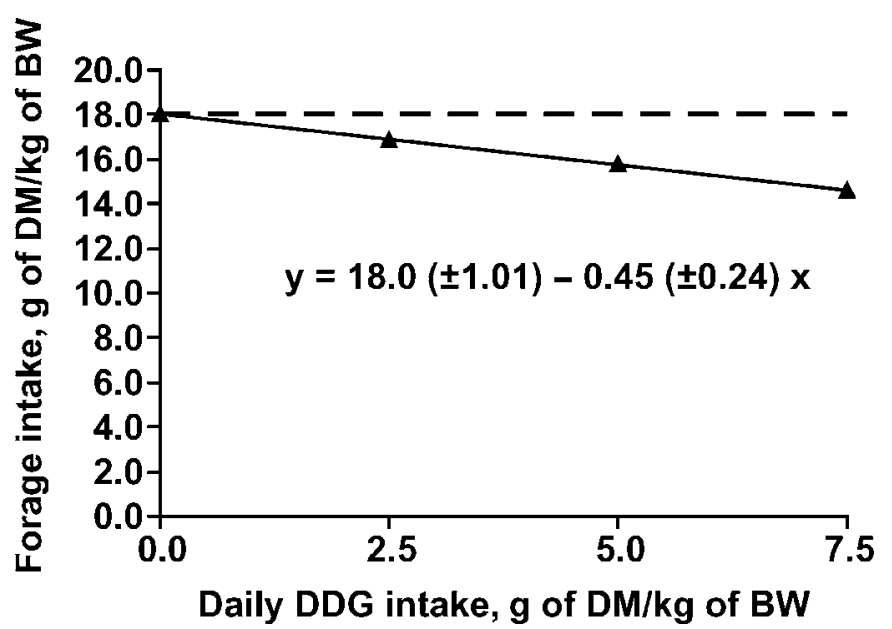

Figure 4. Effects of dried distillers grains (DDG) supplementation on forage intake estimated from an energetic model based on NE equations [NRC (1996) and Morris et al. (2005)]. The dashed line is a reference value for the response of nonsupplemented control heifers. DDG slope different from $0(P=0.07)$.

energetic model agree and may suggest that the chromic oxide analysis was not sensitive enough to detect the reduction in forage intake. Limitations exist for both methods employed to estimate forage intake. Heifers that did not consume their entire allotment of supplement had lower-than-expected chromic oxide intake. Although this was accounted for by determination of orts, low chromic oxide flow may have added error to the forage intake analysis, which could have reduced the sensitivity of the analysis. Additionally, both the chromic oxide analysis and energetic model rely on digestibility estimates from TTDMD (Table 3 ). Several factors are known to affect fiber digestion including level of intake (Scholljegerdes et al., 2004) and interactions with supplementation strategy (Hannah et al., 1990; Loy et al., 2007). Although the methods of Geisert et al. (2006) used to correct IVDMD to TTDMD were conducted at ad libitum forage intake, the chromic oxide method assumes static forage digestibility across types and levels of supplementation. Our method of separating fecal output into indigestible components from forage and supplement also ignores the effects of forage-supplement interactions. Although separation of fecal components from forage and supplement is justified (Bowman et al., 1999), it is unlikely that forage and supplement digestibilities remain static when combined in vivo. Effects of DDG supplementation on forage digestibility are accounted for in the energetic model within the range of supplementation utilized by Morris et al. (2005), yet this method assumes that forage digestibility in the current study reacts similarly to DDG supplementation as did the forage in the study of Morris et al. (2005). In light of these known limitations, estimates from the current study, in which grazing cattle were used, appear to be consistent with other data in which forage intake was measured directly. Data from a growing trial by Loy et al. (2003), who fed 2 levels of DDG and measured forage intake, reported a replacement of -0.41 within the range of DDG fed. Data from a complementary metabolism trial (Loy et al., 2007) demonstrated a replacement of -0.55 when comparing nonsupplemented controls to heifers consuming DDG at $0.40 \%$ of BW daily. A primary objective of the current study was to estimate forage intake for cattle consuming DDG and grazing actively growing forage. These data appear to be consistent with data in which forage was provided in a bunk and intake was directly measured. Taken together, these data provide strong evidence that DDG replaces forage at a rate of approximately $50 \%$ of the amount supplemented for cattle receiving up to $7.5 \mathrm{~g}$ of DDG (DM) per kilogram of BW.

Both CGM (Figure 2) and OIL (Figure 3) resulted in forage replacement rates similar to DDG $(P=0.19$ and 0.73 for comparisons of DDG vs. CGM and OIL, respectively). However, although the decline in forage intake for OIL was not different from $0(P=0.42)$, the effect of CGM on forage intake was significant $(P<$ 0.01 ) and may suggest that UIP supplementation reduces forage intake. However, it may be unlikely that UIP is driving any potential reduction in forage intake by DDG, because the response to OIL was not different from DDG. The reduction in forage intake due to CGM supplementation is unexplained but may be related to an endocrine response. Protein and fats are known to induce satiety, perhaps because they cause the release of cholecystokinin (Forbes, 1996; Sutton et al., 2005). Therefore, these observations could be related to cholecystokinin release from UIP, but it is curious that a similar response was not observed for OIL. This reduction in forage intake may explain performance data associated with UIP supplementation observed by others. Creighton et al. (2003) reported a decline in ADG when UIP was provided in excess of the amount required. This observation was unexplained, because animals would be expected to utilize excess protein for energy. Perhaps the reduction in ADG reported by Creighton et al. (2003) could be explained by decreased forage intake due to excess UIP supplementation. However, additional research investigating effects of UIP on forage intake is needed before conclusions can be drawn.

When evaluated alone, DDG supplementation did not appear to affect BCP flow $(P=0.29$; Figure 1$)$. However, when compared with UIP and OIL (Figures 2 and 3, respectively), DDG supplementation increased PD:C above control in a quadratic response $(P<0.05)$. Loy et al. (2007) reported an increase in PD:C due to DDG supplementation. It is likely that evaluating DDG-supplemented cattle alone reduced degrees of freedom for error such that an effect on BCP flow was not detected. Although CGM had no effect on BCP flow $(P=0.56)$, OIL increased $\mathrm{PD}: \mathrm{C}$ in a manner similar to DDG. Others have reported a decline in microbial 
$\mathrm{N}$ flow when soybean oil was supplemented to heifers grazing actively growing bromegrass pastures (Brokaw et al., 2001), whereas we concluded from our data that microbial $\mathrm{N}$ increased with corn oil supplementation. However, the OIL supplement may have provided substantial fermentable carbohydrate due to the inclusion of corn bran carrier as indicated by NDF analysis of supplement ingredients (Table 2). It should be recognized that all NDF is not available for ruminal fermentation. However, the NDF in corn bran has been shown to be rapidly and highly fermentable in the rumen (Firkins et al., 1985), and thus, NDF seems a reasonable indicator of fermentable carbohydrate capable of producing BCP. Therefore, we caution that the increase in PD:C may be due to the corn bran carrier rather than the EE that was intended to be tested. It is likely that the increase in BCP flow from DDG supplementation is due to the fermentable carbohydrate (estimated as NDF, Table 2) it provides.

In conclusion, supplementation of actively growing forages with DDG increases ADG and reduces forage intake. Providing UIP equal to the concentration in DDG results in gains $39 \%$ as great as those observed for dried distillers grain, suggesting roughly one-third of the response to distillers grains may be due to meeting a MP deficiency. Although providing fat equal to that found in distillers grains provides no additional gain, an associative effect of providing a combination of protein and energy from UIP and fat may be responsible for the additional gain observed from DDG supplementation. Current estimates suggest that DDG will replace grazed forage at a rate of approximately $50 \%$ of the amount supplemented for cattle receiving up to $7.5 \mathrm{~g}$ of DDG per kilogram of BW. This equates to a possible 10 to $20 \%$ increase in stocking rate by supplementing DDG from 0.50 to $0.75 \%$ of $\mathrm{BW}$ daily to cattle that would consume $2.0 \%$ of BW daily of forage when not supplemented.

\section{LITERATURE CITED}

AOAC. 1996. Official Methods of Analysis. 16th ed. Assoc. Offic. Anal. Chem., Arlington, VA.

Block, H. C., T. J. Klopfenstein, and G. E. Erickson. 2006. Evaluation of average daily gain prediction by level one of the $1996 \mathrm{Na}$ tional Research Council beef model and development of NE adjusters. J. Anim. Sci. 84:866-876.

Bowman, J. G. P., B. F. Sowell, D. L. Boss, and H. Sherwood. 1999. Influence of liquid supplement delivery method on forage and supplement intake by grazing beef cow. Anim. Feed Sci. Technol. 78:273-285.

Brokaw, L., B. W. Hess, and D. C. Rule. 2001. Supplemental soybean oil or corn for beef heifers grazing summer pasture: Effects on forage intake, ruminal fermentation, and site and extent of digestion. J. Anim. Sci. 79:2704-2712.

Creighton, K. W., C. B. Wilson, T. J. Klopfenstein, and D. C. Adams. 2003. Undegradable intake protein supplementation of compensating spring-born steers and summer-born steers during summer grazing. J. Anim. Sci. 81:791-799.

Firkins, J. L., L. L. Berger, and G. C. Fahey Jr. 1985. Evaluation of wet and dry distillers grains and wet and dry corn gluten feed for ruminants. J. Anim. Sci. 60:847-860.
Forbes, J. M. 1996. Integration of regulatory signals controlling forage intake in ruminants. J. Anim. Sci. 74:3029-3035.

Geisert, B. G., T. J. Klopfenstein, D. C. Adams, and J. C. MacDonald. 2006. Comparison of in vivo digestibility to in vitro digestibility of five forages fed to steers. J. Anim. Sci. 84(Suppl. 2):104. (Abstr.)

Goedeken, F. K., T. J. Klopfenstein, R. A. Stock, and R. A. Britton. 1990. Hydrolyzed feather meal as a protein source for growing calves. J. Anim. Sci. 68:2945-2953.

Hannah, S. M., J. A. Paterson, J. E. Williams, and M. S. Kerley. 1990. Effects of corn vs. corn gluten feed on site, extent and ruminal rate of forage digestion and on rate and efficiency of gain. J. Anim. Sci. 68:2536-2545.

Haugen, H. L., S. K. Ivan, J. C. MacDonald, and T. J. Klopfenstein. 2006a. Determination of undegradable intake protein digestibility of forages using the mobile nylon bag technique. J. Anim. Sci. 84:886-893.

Haugen, H. L., M. J. Lamothe, T. J. Klopfenstein, D. C. Adams, and M. D. Ullerich. 2006b. Estimation of undegradable intake protein in forages using neutral detergent insoluble nitrogen at a single in situ incubation time point. J. Anim. Sci. 84:651-659.

Klopfenstein, T. J. 1996. Need for escape protein by grazing cattle. Anim. Feed Sci. Technol. 60:191-199.

Leonardi, C., S. Bertics, and L. E. Armentano. 2005. Effect of increasing oil from distillers grains or corn oil on lactation performance. J. Dairy Sci. 88:2820-2827.

Littell, R. C., W. W. Stroup, and R. J. Freund. 2002. SAS for Linear Models. 4th ed. SAS Inst. Inc., Cary, NC.

Loy, T. W., T. J. Klopfenstein, G. E. Erickson, C. N. Macken, and J. C. MacDonald. 2003. Supplemental type and frequency on intake, performance, and energy value of dry distillers grains in a high-forage diet. J. Anim. Sci. 81(Suppl. 2):107. (Abstr.)

Loy, T. W., J. C. MacDonald, T. J. Klopfenstein, and G. E. Erickson. 2007. Effect of distillers grains or corn supplementation frequency on forage intake and digestibility. J. Anim. Sci. 85:2625-2630.

MacDonald, J. C. 2006. Use of dried distillers grains and nitrogen sources in high-forage diets. PhD Diss. Univ. Nebraska, Lincoln.

Morris, S. E., T. J. Klopfenstein, D. C. Adams, G. E. Erickson, and K. J. Vander Pol. 2005. The effects of dried distillers grains on heifers consuming low or high-quality forage. Nebraska Beef Cattle Report. MP 83-A:18-20.

NRC. 1996. Nutrient Requirements of Beef Cattle. Natl. Acad. Press, Washington, DC.

Oba, M., and M. S. Allen. 1999. Evaluation of the importance of the digestibility of neutral detergent fiber from forage: Effects on dry matter intake and milk yield of dairy cows. J. Dairy Sci. 82:589-596.

Owens, F. N., M. A. Hinds, and D. W. Rice. 2002. Methods for calculating diet energy values from feedlot performance of cattle. J. Anim. Sci. 80(Suppl. 1):273. (Abstr.)

Patterson, T., T. Klopfenstein, T. Milton, and D. Brink. 2000. Evaluation of the 1996 beef cattle NRC model predictions of intake and gain for calves fed low or medium energy density diets. Pages 26-29 in 2000 Nebraska Beef Report. MP 73-A. Univ. Nebraska, Lincoln.

Paven, E., S. K. Duckett, and J. G. Andrae. 2007. Corn oil supplementation to steers grazing endophyte-free tall fescue. I. Effects on in vivo digestibility, performance, and carcass traits. J. Anim. Sci. 85:1330-1339.

Scholljegerdes, E. P., P. A. Ludden, and B. W. Hess. 2004. Site and extent of digestion and amino acid flow to the small intestine in beef cattle consuming limited amounts of forage. J. Anim. Sci. 82:1146-1156.

Shingfield, K. J., and N. W. Offer. 1998. Evaluation of the spot urine sampling technique to assess urinary purine derivative excretion in lactating dairy cows. J. Anim. Sci. 66:557-568.

Shingfield, K. J., and N. W. Offer. 1999. Simultaneous determination of purine metabolites, creatinine, and pseudouridine in ruminant urine by reverse-phase high-performance liquid chromatography. J. Chromatogr. B 723:81-94. 
Sutton, G. M., B. Duos, L. M. Patterson, and H. R. Berthoud. 2005. Melanocortinergic modulation of cholecystokinin-induced suppression of feeding through extracellular signal-regulated kinase signaling in rat solitary nucleus. Endocrinology 146:3739-3747.

Tilley, J. M. A., and R. A. Terry. 1963. A two-stage technique for the in vitro digestion of forage crops. J. Br. Grassl. Soc. 18:104-111.

Van Soest, P. J., J. B. Robertson, and B. A. Lewis. 1991. Methods for dietary fiber, neutral detergent fiber, and nonstarch polysac- charides in relation to animal nutrition. J. Dairy Sci. 74:3583-3597.

Weiss, W. P. 1994. Estimation of digestibility of forages by laboratory methods. Page 644 in Forage Quality, Evaluation and Utilization. G. C. Fahey Jr., ed. Am. Soc. Agron., Crop Sci. Soc. Am., Soil Sci. Soc. Am., Madison, WI.

Williams, C. H., D. J. David, and O. Iismaa. 1962. The determination of chromic oxide in feces samples by atomic absorption spectrophotometry. J. Agric. Sci. Camb. 59:381-385. 